\title{
Pengaruh Metode Hypnolearning Terhadap Prestasi Belajar Bahasa Arab Siswa Kelas VIII MTS. Darussalam Impa-Impa
}

\author{
Yusril Ihza Mahendra ${ }^{\mathrm{a}, 1}$, Andi Bunyamin ${ }^{\mathrm{a}, 2}$, Ratika Nengsih ${ }^{\mathrm{a}, 3}$ \\ ${ }^{a}$ Universitas Muslim Indonesia \\ ${ }^{1}$ raisyusril@gamil.com, ${ }^{2}$ bunyamin.andi@yahoo.co.id, ${ }^{3}$ ratika.nengsi@umi.ac.id
}

\begin{abstract}
Abstrak
Penelitian ini adalah penelitian Asosiatif yang bertujuan untuk mengetahui sejauh mana pengaruh metode hypnolearning terhadap prestasi belajar Bahasa Arab siswa kelas VIII MTs Darussalam ImpaImpa Kabupaten Wajo. Subyek penelitian ini adalah siswa kelas VIII MTs Darussalam Impa-Impa tahun pelajaran 2019/2020 semester genap sebanyak 36 siswa yang terdiri dari 16 laki-laki dan 20 perempuan. Penelitian dilaksanakan memalui lima tahapan yaitu, Identifikasi Masalah, Tes Diagnostik, klasifikasi kelas, Hypnoterapi/Hypnolearning,, Tes Prestasi, Refleksi. Teknik pengumpulan data yang digunakan adalah observasi, tes, angket, dan dokumentasi. Menganalisis data dengan analisis kuantitatif. Hasil yang diperoleh dari analisis kuantatif adalah pengaruh yang signifikan antara metode hypnolearning dengan prestasi belajar pada mata pelajaran bahasa arab yang ditandai dengan siswa memperhatikan penjelasan pada saat kegiatan belajar mengajar, keatiktifan dalam bertanya, berani menyampaikan pendapat, antusias mengerjakan tugas , serta kemampuan dalam menjawab pentanyaan dengan persentase prestasi belajar $82,6 \%$. jadi isimpulkan bahwa terpengaruh yang signifikan metode Hynolearning pada prestasi belajar Bahasa Arab siswa MTs Darussalam Impa-Impa Kabupaten Wajo.
\end{abstract}

Kata Kunci: Hynolearning, prestasi belajar, belajar Bahasa Arab

\section{Pendahuluan}

Umumnya, pendidikan adalah aktivitas universal masyarakat dalam kehidupan. Walaupun pendidikan merupakan gejala umum pada setiap aktivitas masyarakat, namun perbedaan prinsip hidup yang dianut masing-masing bangsa menyebabkan terjadinya perbedaan penyelengaraan termasuk kapasitas suatu pendidikan.

Kualitas Pendidikan memiliki kaitan dengan tingkat kemampuan belajar individu yang berkualitas, hal itulah yang menjadi patokan melalui kegiatan belajar mengajar. Proses pembelajaran dapat menjadi acuan siswa dalam mengukur kemampuan siswa, diharapkan siswa mampu menimba ilmu dan wawasan seoptimal mungkin dengan belajar. Belajar adalah suatu cara yang didalamnya memiliki korelasi antara individu dengan individu, dan individu dengan lingkungannya. ${ }^{1}$

Adanya proses tersebut akan memberikan refleksi pada perubahan siswa, baik berupa pengetahuan, tingkah laku yang akan menjadi standar keberhasilan siswa dalam belajar yang disebut dengan prestasi belajar. ${ }^{2}$

Dari hal diatas dapat dijelaskan bahwa prestasi belajar dapat diukur bila siswa mendapatkan perubahan baik pengetahuan, tingkah, serta wawasan yang sebanyak banyaknya pada Pendidikan yang berkualitas.

\footnotetext{
${ }^{1}$ Rosyid Zaiful Muh,Et.Al , Prestasi Belajar, (Malang:Literasi Nusantara Abadi, 2019), h.3

${ }^{2}$ Ibid, h.5
} 
Prestasi Belajar merupakan kemampuan individu yang dimiliki setelah melakukan usaha dalam belajar baik di lingkungan sekolah atau diluar sekolah ${ }^{3}$. Prestasi merupakan interaksi antara keluarga, sekolah, serta lingkungan setempat. Salah satu hal dalam tujuan adalah adanya perubahan dalam diri siswa. Meningkatnya kemampuan yang dimiliki siswa baik dari segi menanggapi, menyanggah, dan mengevaluasi informasi-informasi yang diperoleh dari aktivitas belajar mengajar. Perubahan tersebut diharapkan dapat mengarah ke hal yang lebih bijak dan inovatif . Dalam aktivitas belajar tingkat keberhasilan dalam suatu subjek dinyatakan dalam bentuk angka atau nilai rapor setelah terlaksananya kegiatan belajar mengajar mengajar melalui evaluasi. Belajar dipengaruhi oleh berbagai hal. Hal tersebut dapat menentukan baik tidaknya suatu proses belajar ${ }^{4}$.

Jadi dari beberapa definisi diatas disimpulkan bahwa prestasi belajar merupakan usaha yang dilakukan suatu individu dalam meningkatkan mutu kualitas belajar yang diperoleh melalui kemampuan yang dimiliki siswa baik dari segi hal menanggapi, menyanggah dan mengevaluasi informasi.

Adapun hal yang dapat mempengaruhi belajar digolongan pada dua bagian, yaitu faktor internal dan eksternal. Faktor internal adalah apa yang dimiliki dalam diri individu yang sedang belajar baik berupa fisiologis (keadaan fisik dan Indera) maupun psikologis (psikomotorik, afektif, intelegensi, kemauan, kognitif, kematangan, dan perhatian). Sementara faktor eksternal adalah apa yang ada diluar individu baik lingkungan (keluarga dan masyarakat) maupun instrumental (kurikulum, metode, media, sarana, prasarana, dan guru).

Pendidikan merupakan komponen yang sangat penting dan menjadi pusat dalam peningkatan kualitas Sumber Daya Manusia (SDM), sebagaimana yang tercantum dalam konsep pendidikan UU No. 20 Tahun 2003 bahwa :

"Pendidikan adalah usaha sadar dan terancam untuk mewujudkan suasana belajar dan proses pembelajaran agar peserta didik secara aktif mengembangkan potensi dirinya untuk memiliki kekuatan spiritual keagamaan, pengendalian diri, kepribadian, kecerdasan, akhlak mulia, serta keterampilan yang diperlukan dirinya, masyarakat bangsa dan negara".

Kualitas suatu Pendidikan yaitu mampu menghasilkan sumber daya manusia yang bermanfaat, produktif, dan progresif. Hal yang dapat mempengaruhi tercapainya suatu tujuan pendidikan salah satunya adalah lahirnya Sumber Daya Manusia yang produktif, serta pendidikan yang berkualitas . Maka proses belajar adalah tahapan dalam menunjang kualitas pendidikan tersebut.

Kualitas dalam proses belajar dipengaruhi oleh tindakan guru yang berperan aktif secara langsung sebagai penanggung jawab terhadap kegiatan belajar mengajar yang berlangsung. Selain guru, dalam meningkatkan mutu pendidikan siswa sangat berperan penting di dalamnya karena merupakan inti dalam proses belajar mengajar. Jadi, Meningkatnya mutu pendidikan harus di barengi dengan hasil dan prestasi belajar yang optimal sehingga dapat meningkatkan mutu belajar siswa.

Prestasi belajar siswa sangat menentukan tinggi rendahnya keberhasilan dalam kegiatan belajarnya. Bila prestasi belajarnya tinggi menandakan bahwa tujuan pembelajaran tercapai dengan baik, sebaliknya bila prestasi belajar tersebut rendah maka tujuan belajar belum terlaksana secara optimal. Untuk memperoleh prestasi, bukanlah suatu perkara yang mudah, olehnya itu pencapaian prestasi belajar siswa dipengaruhi oleh berbagai macam faktor dan memerlukan kemampuan dan keinginan yang kuat untuk meraihnya.

Keberhasilan seseorang disebabkan oleh beberapa hal yang mempengaruhi hasil pencapaian belajar adalah masalah internal dan eksternal. Faktor internal berarti orang yang belajar yang meliputi kamauan, sehat, intelegensi, kognitif, psikomotorik, dan bakat. Dan eksternal meliputi lingkungan keluarga, sekolah,dan masyarakat.

\footnotetext{
${ }^{3}$ Ula Shoimatul.S, Revolusi Belajar, (Yogyakarta:Ar-Ruzz Media, 2013), h.22

${ }^{4}$ Ibid, h.17
} 
Metode pada intinya memiliki tujuan dalam menghidupkan pembelajaran yang kondusif yang agar siswa dapat antusias dan terdorong mengikuti sebuah pembelajaran demi menggapai hasil belajar yang cemerlang. Metode yang dapat meningkatkan prestasi belajar siswa di sekolah salah satunya adalah metode Hypnolearning.

Metode Hypnolearning merupakan pola untuk mengajarkan kepada siswa fokus, menikmati belajar, juga senang dan semangat dalam belajar. Dengan memadukan nilai-nilai ini, siswa akan diajarkan untuk dengan baik menjadi sarana untuk meningkatkan potensi belajar ${ }^{5}$

Hypnolearning adalah hipnosis yang digunakan dalam kegiatam belajar untuk memunculkan potensi diri atau meningkatkan prestasi belajar siswa. ${ }^{6}$

Setelah melakukan pengamatan lapangan di MTs. Darussalam Impa-Impa, Kec. Tanasitolo, Kab. Wajo, dengan Kepala Sekolah bernama Bapak Drs. Muh. Rais, M.M, Guru Mata Pelajaran Bahasa Arab bernama Drs. Abu Hamid Arsyad jumlah guru 21 orang dan jumlah murid 122 orang serta jumlah siswa kelas VIII 36 orang, informasi yang kami dapatkan bahwa metode Hypnolearning telah digunakan dalam kegiatan belajar mengajar pelajaran Bahasa Arab untuk mencapai prestasi belajar di kelas tersebut. Hal ini ditandai dengan aktivitas guru yang mengaplikasikan metode Hypnolearning seperti guru mengidentifikasi masalah serta mengklasifikasi siswa untuk semangat belajar, menggunakan ucapan positif dalam membangun motivasi siswa, memberi apresiasi kepada siswa yang melakukan hal yang baik, dan menjadi figur serta teladan yang baik. ${ }^{7}$

Peserta didik memiki antusias ketika kegiatan belajar mengajar sedang berlangsung. Dapat dilihat pada saat siswa berani mengajukan pertanyaan dan pernyataan serta mereka segera mengajukan pertanyaan tentang materi yang mereka ingin pahami atau yang tidak sama sekali mereka pelajari. Namun, masih ada siswa yang kurang antusias dalam pelaksanaan metode Hypnolearning tersebut. Prestasinya pun bisa dikatakan mereka masih rendah. Hal ini dapat diperhatikan dari fakta di lapangan antara lain :

a. Siswa enggan menyelesaikan tugas dari guru,

b. Munculnya rasa kurang percaya diri ketika mendapatkan kesulitan dalam belajar,

c. Beberapa siswa yang kurang berani dalam memaparkan pertanyaan atau pernyataan.

d. Rasa pesimis yang berlebihan sehingga siswa kurang berminat untuk belajar.

e. Adanya kesulitan tugas-tugas akademik.

f. Adanya kesenjangan antara prestasi dan potensi.

Realitas diatas menandakan bahwa adanya masalah dalam belajar siswa, disisi lain upaya guru semaksimal mungkin untuk meningkatkan prestasi belajar pada mata pelajaran Bahasa Arab akan tetapi disisi masih ada prestasi belajar siswanya yang tergolong sedang.

Berdasarkan fakta diatas maka diperlukan penelitian yang lebih mendalam tentang kelas VIII MTs. Darussalam Impa-Impa memiliki motivasi dalam pembelajaran Bahasa Arab, yang penulis buat dengan judul "Pengaruh Metode Hypnolearning Terhadap Prestasi Belajar Bahasa Arab Siswa Kelas VII Mts Darussalam Impa-Impa Kabupaten Wajo" dengan penelitian Kuantitatif.

\section{Manfaat Penelitia}

\subsection{Manfaat Teoritis} berikut:

Dari segi teoritis, penelitian ini memberikan manfaat dari berbagai aspek diantaranya sebagai

a. Pengembangan wawasan, memperkaya teori-teori bagi pengembangan di bidang pendidikan terhadap pengaruh Hypnolearning terhadap pretasi belajar Bahasa Arab siswa.

\footnotetext{
${ }^{5}$ Abbas Rustan Ibnu, Dahsyatnya Spiritual Hypnolearning,(Emir:2016), h.21.

${ }^{6}$ Mahardika Deni, Menerapkan Hypno Studying, (Yogyakarta:Diva Press, 2015), h.13

${ }^{7}$ Hasil observasi sekolah MTs. Darussalam Impa-Impa pada tanggal 19 November 2019
} 
b. Pengembangan ilmu pengetahuan mengenai komposisi belajar dalam kegiatan belajar mengajar terutama pada metode dalam meningkatkan kualitas Pendidikan di sekolah.

c. Sebagai salah satu model yang bermanfaat pada suatu proses pembelajaran.

\subsection{Manfaat Praktis}

Di antara manfaat praktis pada penelitian ini adalah sebagai berikut:

a. Dapat dijadikan sebagai langkah awal dalam melakukan penelitian lebih lanjut .

b. Menjadi salah satu metode yang mampu mendongkrak prestasi belajar siswa melalui sistem pembelajaran yang santai dan menarik untuk dipelajari.

c. Dapat digunakan sebagai metode yang dapat diaplikasikan dalam mengembangkan potensi belajar siswa.

d. Sebagai inovasi dalam mentransfer ilmu pengetahuan kepada siswa.

e. Sebagai salah satu Instrumen dalam mencapai tujuan Pendidikan.

\section{Metode Penelitian}

Peneliti menggunakan metode penelitian kuantitatif dengan metode asosiatif. Metode asosiatif digunakan sebagai tolok ukur untuk mengetahui sejauh mana pengaruh metode Hypnolearning terhadap prestasi belajar bahasa Arab siswa.

Teknik pengumpulan data menggunakan observasi langsung dan tidak langsung untuk mengamati hal-hal terkait dengan permasalahan yang akan diteliti, inventori belajar sebagai alat untuk penelitian berupa daftar kemampuan yang berisi pertanyaan secara tertulis yang akan dijawab oleh responden sesuai dengan petunjuk untuk mengukur kepribadian atau kemampuan seseorang.

Adapun Teknik Analisis data yang diambil untuk mengetahui Pengaruh Hypnolearning terhadap motivasi belajar bahasa Arab siswa yaitu dengan mengelolah jawaban dari para responden dengan menggunakan skala Likert dengan kisaran 1-5 dengan jawaban alternatif jawaban sebagai berikut:

$\begin{array}{ll}\text { Sangat Tidak Setuju } & =1 \\ \text { Tidak Setuju } & =2 \\ \text { Kurang Setuju } & =3 \\ \text { Setuju } & =4 \\ \text { Sangat Setuju } & =5\end{array}$

Uji normalitas dan homogenitas adalah pengujian sebelum menggunakan analisis data. Fungsi dari uji normalitas dan homogenitas adalah untuk mengetahui kenormalan distribusi searah dengan skor variabel yang telah diuji merupakan variabel dependen dan independen sedangkan homogenitas untuk membuktikan data yang telah dianalisis sebelumnya berasal dari populasi yang tidak jauh dari variannya.

Setelah dilakukan uji normalitas dan homogenitasnya maka peneliti akan menguji instrumen penelitian. Pengujian agar mendapatkan instrumen yang layak digunakan.

\section{a. Uji Validitas}

Uji validitas instrument dilakukan dengan menggunakan kesahihan butir, dengan teknik korelasi product moment. Untuk menguji skor butir dengan skor total digunakan derajat kebebasan $\boldsymbol{\alpha}=\mathbf{0 , 5}(\mathbf{5} \%)$. Uji validitas instrument dilakukan penyesuaian terhadap beberapa orang responden sebagai sampel terhadap uji coba diluar responden yang dilakukan melalui sampel penelitian. Instrument dianggap valid apabila $\mathbf{r}_{\text {hitung }}>\mathbf{r}_{\text {tabel. }}$.

$$
r=\frac{n \sum x y-\left(\sum x\right)\left(\sum y\right)}{\left.\sqrt{\left\{N \sum x^{2}\right.}-\left(\sum x\right)^{2}\right\}\left\{N \sum y^{2}-\left(\sum y\right)^{2}\right\}}
$$

Keterangan:

$\mathrm{r}=$ koefisien korelasi

$\mathrm{N}=$ Jumlah sampel yang diteliti

$\mathrm{X}=$ Variabel bebas

$\mathrm{Y}=$ Variabel Terikat 


\section{b. Uji Reliabilitas}

Perhitungan reliabilitas butir instrumen penelitian dikatakan reliable apabila nilai koefisien Alpha Cronbach lebih besar dari $0,6(\alpha \geq 0,6)$, sebaliknya bila angka koefisien reliabilitas yang diperoleh tersebut dibawah $0,6(\alpha \leq 0,6)$ maka dianggap kusioner tersebut tidak realiabel atau dianggap tidak cukup baik dalam mengukur persepsi responden pada variabel yang telah diteliti.

$$
r_{\mathrm{ac}}=\left(\frac{k}{k-1}\right)\left[1-\frac{\sum \sigma_{b}^{2}}{\sigma_{t}{ }^{2}}\right]
$$

$$
\begin{aligned}
& \text { Keterangan } \\
& \mathrm{r}_{\mathrm{ac}} \quad=\text { Koefisien reliabilitas alpha cronbach } \\
& \mathrm{k}=\text { Banyak butir / item pertanyaan } \\
& \sum \sigma_{\mathrm{b}}{ }^{2} \quad=\text { Jumlah/total varian perbutir } \\
& \sum \sigma_{\mathrm{t}}^{2} \quad=\text { Jumlah atau total varian }
\end{aligned}
$$

\section{Hasil Penelitian}

Uji Instrumen yang dilakukan terhadap siswa MTs. Darussalam Impa-Impa kelas VIII sebanyak 36 dengan pertanyaan 48 pertanyaan yang terdiri dari 24 soal untuk hypnolearning dan 24 soal untuk prestasi belajar.

\subsection{Data Validitas}

Data uji instrumen ini diolah dengan MS Axcel. Setiap butir soal dikatakan valid bila $r_{\text {hitung }}$ $>r_{\text {tabel }}$ dengan taraf signifikan sebesar $5 \%$. Nilai $r_{\text {tabel }}$ dalam tabel product moment sebesar 0,3202. Uji validitas ini merupakan validitas sementara. Adapun hasil uji validitas dapat dilihat pada tabel sebagai berikut :

Tabel. Hasil Uji Validitas

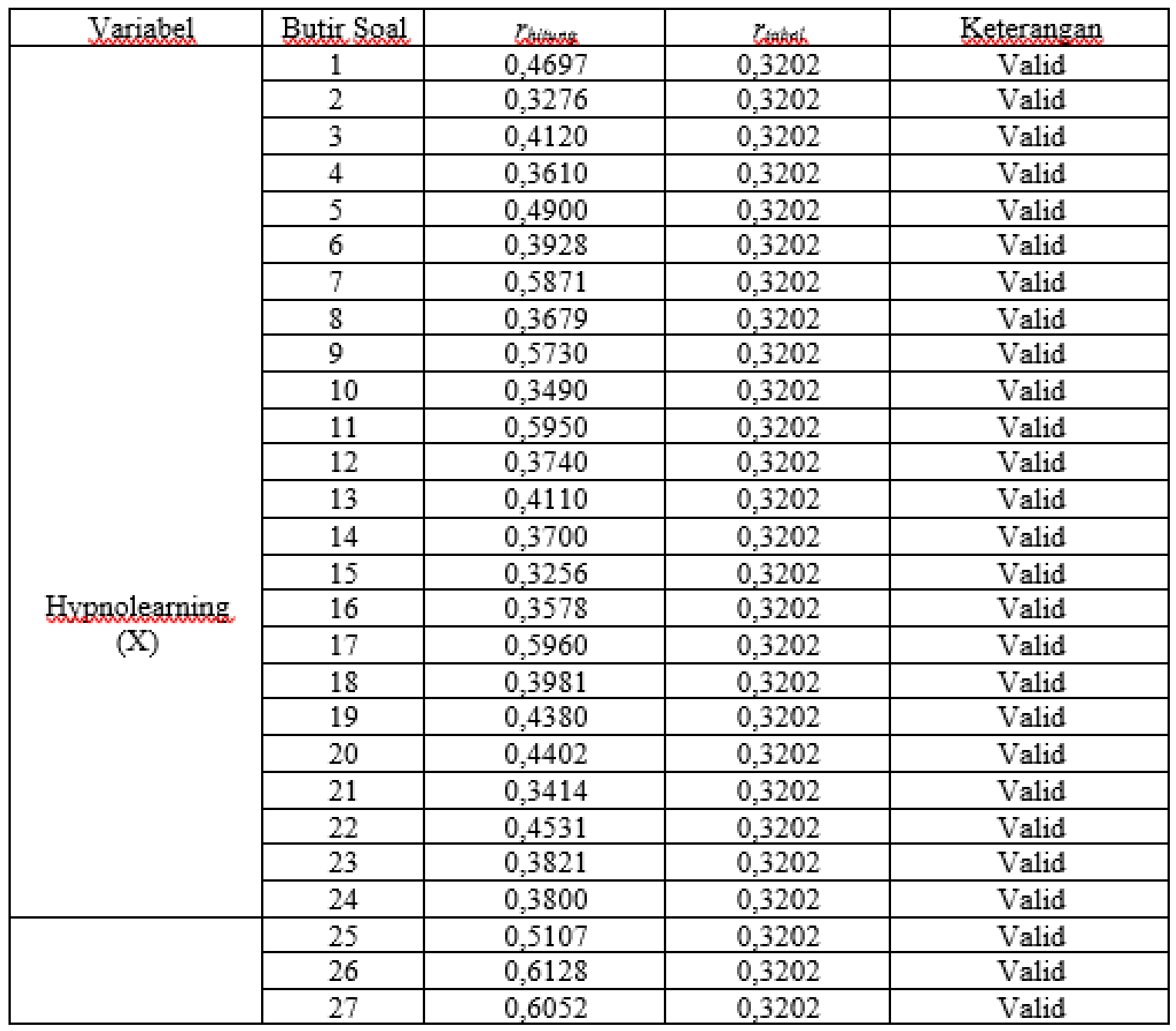




\begin{tabular}{|c|c|c|c|c|}
\hline \multirow{21}{*}{ Prestasi Belajar } & 28 & 0,6685 & 0,3202 & Valid \\
\hline & 29 & 0.3300 & 0,3202 & Valid \\
\hline & 30 & 0,3936 & 0,3202 & Valid \\
\hline & 31 & 0,6866 & 0,3202 & Valid \\
\hline & 32 & 0,3370 & 0,3202 & Valid \\
\hline & 33 & 0,8070 & 0,3202 & Valid \\
\hline & 34 & 0,3380 & 0,3202 & Valid \\
\hline & 35 & 0,6250 & 0,3202 & Valid \\
\hline & 36 & 0,583 & 0,3202 & Valid \\
\hline & 37 & 0,5180 & 0,3202 & Valid \\
\hline & 38 & 0,3400 & 0,3202 & Valid \\
\hline & 39 & 0,4105 & 0,3202 & Valid \\
\hline & 40 & 0,5026 & 0,3202 & Valid \\
\hline & 41 & 0,7953 & 0,3202 & Valid \\
\hline & 42 & 0,4504 & 0,3202 & Valid \\
\hline & 43 & 0,3370 & 0,3202 & Valid \\
\hline & 44 & 0,3552 & 0,3202 & Valid \\
\hline & 45 & 0,3486 & 0,3202 & Valid \\
\hline & 46 & 0,7324 & 0,3202 & Valid \\
\hline & 47 & 0,3395 & 0,3202 & Valid \\
\hline & 48 & 0,8970 & 0,3202 & Valid \\
\hline
\end{tabular}

Sumber: Hasil Pengolahan MS Excel

Berdasarkan tabel diatas dapat diketahui bahwa soal yang diberikan dengan 48 butir soal untuk tes penguasaan mufradat terdapat 48 butir valid dan 0 butir tidak valid, 24 butir soal hypnolearning dan 24 butir prestasi belajar semua valid. Selanjutnya untuk butir soal yang tidak valid tidak diikutkan dalam uji reliabilitas.

Tabel Hasil Uji Reliabilitas

\begin{tabular}{|c|c|c|c|}
\hline Variabel Penelitian & Cronbach Alpha & Batas Reabilitas & Keterangan \\
\hline Hypnolearning & 0,7964 & 0,60 & Reliabel \\
\hline Prestasi Belajar & 0,8916 & 0,60 & Reliabel \\
\hline
\end{tabular}

Sumber: Hasil Pengolahan MS Excel

Berdasarkan tabel diatas, maka diketahui hasil pengujian reliabilitas Cronbach Alpha pada angka variabel Hypnolearning lebih besar dari batas reliabel 0,79>0,60, sehingga instrument dinyatakan reliabel. Pada variabel prestasi belajar, Cronbach Alpha juga lebih besar dari batas reliabel $0,89>0,60$. Oleh karena itu bahwa variabel tersebut dinyatakan reliabel.

\subsection{Deskripsi Data}

Penelitian ini peneliti membahas dua variabel yang terdiri dari satu variabel bebas yaitu, yaitu Hypnolearning (X) dan satu variabel terikat yaitu Prestasi Belajar $(\mathrm{Y})$. Untuk menjelaskan dan menguji variabel bebas terhadap variabel terikat pada penelitian ini, maka terlebih dahulu akan dijelaskan deskriptif sebagai gambaran awal data yang diperoleh selama penelitian berlangsung.

\subsection{Uji Prasyarat Analisis}

a. Analisis Regresi Linear sederhana

Tabel Uji Linearitas X dengan Y

\section{REGRESI LINEAR SEDERHANA}

\begin{tabular}{rrr|r|r|r|r} 
Model & \multicolumn{2}{c}{$\begin{array}{c}\text { Sum of } \\
\text { Squares }\end{array}$} & Df & Mean Square & F & Sig. \\
\hline Regression & .828 & & 1 & .828 & .008 & $.929^{\mathrm{b}}$ \\
\hline
\end{tabular}




\begin{tabular}{l|l|l|l|l|l}
\hline Residual & 3479.061 & 34 & 102.325 & \\
\hline Total & 3479.889 & 35 & & \\
\hline
\end{tabular}

a. Dependent Variable: Prestasi Belajar

b. Predictors: (Constant), Hypnolearning

Sumber: Hasil Pengolahan IBM SPSS 25.00

Berdasarkan tabel diatas, hasil olah data melalui SPSS 25.00 menunjukkan bahwa nilai signifikasi 0,929 lebih besar dari 0,05. Sig. Deviation From Linearity $=0,929>0,05$ yang terdapat pengaruh linear antara variabel Hypnolearning (X) dengan Variabel prestasi belajar (Y).

\section{b. Analisis Korelasi Product Moment}

Tabel Korelasi Product Moment

\begin{tabular}{rlrrr} 
& \multicolumn{1}{r}{ X } & \multicolumn{1}{r}{} \\
\hline $\mathrm{X}$ & Pearson Correlation & 1 & -.015 \\
\cline { 2 - 4 } & Sig. (2-tailed) & & .929 \\
\cline { 2 - 4 } & $\mathrm{N}$ & 36 & 36 \\
\hline $\mathrm{Y}$ & Pearson Correlation & -.015 & 1 \\
\cline { 2 - 4 } & Sig. (2-tailed) & .929 & \\
\hline $\mathrm{N}$ & 36 & 36 \\
\hline
\end{tabular}

Sumber: Hasil Pengolahan IBM SPSS 25.00

Berdasarkan tabel diatas, hasil olah data melalui SPSS 25.00 menunjukkan bahwa nilai signifikasi 0,929 lebih besar dari 0,320 ( $\mathrm{r}$ hitung > $\mathrm{r}$ tabel). Maka terdapat hubungan yang signifikan antara variabel Hypnolearning (X) dengan Variabel prestasi belajar (Y).

\subsection{Uji-t}

\section{Tabel Uji-t \\ Paired Samples Test}

\begin{tabular}{|c|c|c|c|c|c|c|c|c|}
\hline & \multicolumn{5}{|c|}{ Paired Differences } & & \multirow[t]{3}{*}{$\mathrm{df}$} & $\begin{array}{l}\text { Sig. (2- } \\
\text { tailed) }\end{array}$ \\
\hline & \multirow[b]{2}{*}{ Mean } & \multirow{2}{*}{$\begin{array}{c}\text { Std. } \\
\text { Deviation }\end{array}$} & \multirow{2}{*}{$\begin{array}{l}\text { Std. Error } \\
\text { Mean }\end{array}$} & \multicolumn{2}{|c|}{$\begin{array}{l}95 \% \text { Confidence } \\
\text { Interval of the } \\
\text { Difference }\end{array}$} & & & \\
\hline & & & & Lower & Upper & & & \\
\hline ir $1 \mathrm{X}-\mathrm{Y}$ & -8.02778 & 13.35982 & 2.22664 & -12.54809 & -3.50746 & -3.605 & 3 & \\
\hline
\end{tabular}

Sumber: Hasil Pengolahan IBM SPSS 25.00

Berdasarkan tabel diatas dapat diketahui bahwa nilai signifikasi uji-t sama dengan 0,001 . dari hal dapat disimpulkan bahwa nilai signifikan $0,001<\alpha=(0,05)$, maka dapat disimpulkan $\mathrm{H}_{0}$ ditolak, artinya terdapat pengaruh yang signifikan antara satu variabel independen terhadap variabel dependen.

\subsection{Faktor-Faktor Hypnolearning terhadap prestasi belajar siswa}

a. Faktor Internal

1) Kecerdasan: Kemampuan siswa dalam menyesuaikan diri terhadap lingkungan sekitar dengan kecakapannya.

2) Jasmani atau Fisiologis: Kondisi jasmani atau sangat mempengaruhi kemampuan belajar siswa karena pancaindra harus berfungsi dengan baik.

3) Sikap: Kecendrungan untuk merasakan reaksi suatu hal seperti suka dengan tidak suka acuh dengan tidak acuh . karena sikap mempengaruhi pengetahuan, kebiasaan, dan keyakinan siswa. 
4) Minat: Suatu kecendrungan dalam mengingat, mengamati, dan memperhatikan secara terus menerus karena atas dasar kesenangan pada diri siswa.

5) Bakat: Potensi yang dimiliki siswa untuk meraih prestasi belajar atau tingkatan tertentu sesuai kemampuan masing masing.

6) Motivasi: Suatu dorongan untuk menggapai apa yang akan diraih siswa dalam suasana belajar.

\section{b. Faktor Eksternal}

1) Keluarga: Merupakan peletak dasar pendidikan dalam pembentukan akhlakul karimah. Dalam hal ini keluarga harus bersinergi dengan guru dalam peningkatan mutu belajar siswa.

2) Lingkungan Sekolah: Guru senantiasa memahami bahan ajar untuk disajikan kepada peserta didik serta menggunakan metode yang menarik dan tepat pada saat kegiatan belajar mengajar.

3) Lingkungan Masyarakat: Lingkungan dalam masyarakat memiliki pengaruh yang kuat terhadap kepribdian anak dalam kehidupan sehari-hari kerena siswa tersebut lebih banyak berinteraksi terhadap lingkungan yang mereka tinggali.

\subsection{Pengaruh metode Hypnolearning terhadap prestasi siswa}

1. Siswa memiliki tujuan belajar

2. Siswa lebih aktif dalam belajar

3. Memperbaiki dan meningkatkan konsentrasi belajar

4. Siswa lebih santai dan mudah belajar

5. Merubah prilaku siswa jadi positif

6. Meningkatkan daya imajinasi, daya khayal perasaan

7. Siswa betah dengan pelajaran yang dibawakan

\subsection{Validasi Intrumen}

Instrumen penelitian telah diperiksa oleh evaluator dengan hasil sebagai berikut:

Tabel Validasi Hypnolearning terhadap prestasi belajar

\begin{tabular}{|c|c|c|c|c|c|c|}
\hline \multirow{2}{*}{$\begin{array}{l}\text { No } \\
\text { I }\end{array}$} & \multirow{2}{*}{\begin{tabular}{l|l} 
Aspek yang ditelaah & \\
Konstruksi &
\end{tabular}} & \multicolumn{5}{|c|}{ Skala Penilaian } \\
\hline & & 1 & 2 & 3 & 4 & 5 \\
\hline & $\begin{array}{l}\text { 1. Pernyataan sesuai dengan rumusan indikator dalam } \\
\text { kisi-kisi. }\end{array}$ & & & & $\sqrt{ }$ & \\
\hline & 2. Pernyataan dirumuskan dengan singkat dan jelas & & & & $\sqrt{ }$ & \\
\hline & $\begin{array}{l}\text { 3. Kalimat yang digunakan bebas dari pernyataan yang } \\
\text { tidak relevan }\end{array}$ & & & $\sqrt{ }$ & & \\
\hline & $\begin{array}{l}\text { 4. Kalimat yang digunakan bebas dari pernyataan yang } \\
\text { bersifat negatif. }\end{array}$ & & & & $\sqrt{ }$ & \\
\hline & $\begin{array}{l}\text { 5. Kalimat yang digunakan bebas dari pernyataan yang } \\
\text { dapat diinterpretasikan lebih dari satu cara }\end{array}$ & & & & $\sqrt{ }$ & \\
\hline & $\begin{array}{l}\text { 6. Kalimat yang digunakan bebas dari pernyataan yang } \\
\text { mungkin disetujui atau dikosongkan oleh semua } \\
\text { responden }\end{array}$ & & & & $\sqrt{ }$ & \\
\hline & $\begin{array}{l}\text { 7. Setiap pernyataan hanya berisi satu gagasan secara } \\
\text { lengkap }\end{array}$ & & & & $\sqrt{ }$ & \\
\hline & 8. Petunjuk mengisi instrumen jelas & & & & & $\sqrt{ }$ \\
\hline & 9. Jumlah butir pernyataan tidak menjemukan responden & & & & & $\sqrt{ }$ \\
\hline \multirow[t]{5}{*}{ II } & Penggunaan Bahasa & & & & & \\
\hline & $\begin{array}{l}\text { 1. Ragam bahasa yang digunakan komunikatif dan sesuai } \\
\text { jenjang pendidikan responden }\end{array}$ & & & & $\sqrt{ }$ & \\
\hline & 2. Pernyataan menggunakan bahasa Indonesia yang baku & & & & $\sqrt{ }$ & \\
\hline & $\begin{array}{l}\text { 3. Pernyataan tidak menggunakan bahasa yang berlaku } \\
\text { ditempat }\end{array}$ & & & & $\sqrt{ }$ & \\
\hline & 4. Kata-kata singkat dan lugas & & & & $\sqrt{ }$ & \\
\hline
\end{tabular}




\section{Kesimpulan}

Berdasarkan dari uraian tersebut terkait pengaruh Hypnolearning terhadap prestasi belajar Bahasa Arab siswa kelas VIII MTs. Darussalam Impa-Impa Kabupaten Wajo, maka sebagai kesimpulan dari pembahasan ini adalah sebagai berikut:

a. Faktor- faktor Hypnolearning terhadap prestasi belajar bahasa Arab siswa kelas VIII MTs. Darussalam Impa-Impa Kabupaten Wajo ada dua yaitu internal dan eksternal. Faktor internal terdiri dari Kecerdasan, Jasmani (Fisiologis), Sikap, Minat, Bakat, dan Motivasi, sedangkan internal terdiri dari Keluarga, Sekolah, dan Lingkungan Masyarakat.

b. Tingkat prestasi prestasi siswa terbilang sangat baik ditandai dengan siswa memperhatikan penjelasan guru, keaktifan siswa dalam bertanya dan berpendapat, antusias siswa mengerjakan tugas serta mampu menjawab pertanyaan yan dipaparkan.

c. Dari hasil analisis data disimpulkan bahwa terdapat pengaruh yang signifikan Hypnolearning pada prestasi belajar Bahasa Arab siswa kelas VIII MTs. Darussalam Impa-Impa Kabupaten Wajo. 


\section{DAFTAR PUSTAKA}

Abbas ibnu Rustan, Dahsyatnya Spiritual Hypnolearning,Emir:2016

Bahri Syaiful, Prestasi Belajar dan Kompetensi Guru. Surabaya.Usaha Nasional, 2017

Dahar Wilis Ratna, Teori Belajar dan Pembelajaran. Bandung.Erlangga,2011

Damopoli Mulyono, Pedoman Karya Tulis Ilmiah Makassar. Alauddin Press, 2013

Fahuddin Syukri, Hypno NLP dalam Proses Belajar Mengajar. Yogyakarta.deepublish, 2018

Fitrah, Muh dan Luthfiyah. Metodologi Penelitian Kualitatif, Tindakan Kelas Dan Studi Kasus. Sukabumi.CV Jejak.2017.

Hasbullah \&Rahmawati,E.Y. Pengaruh Penerapan Metode Hypnoteaching Terhadap Motivasi Belajar Mahasiswa Universitas Indraprasta PGRI. Jurnal Formatif. .2015

Hidayat Junaidi, Bahasa Arab 3.Bogor.Yudistira,2016.

Madiah Noor Fitriyana, Penerapan Hypnoteaching untuk meningkatkan motivasi belajar pada mata kuliah edupreneurship.Yogyakarta.2015

Mahardika Deni, Menerapkan Hypno Studying, Yogyakarta.Diva Press, 2015.

MIF. Baihaqi. Drs., M.Si, Et.al, Psikiatri Konsep Dasar dan Gangguan-Gangguan, Bandung. Revika Editama. 2019.

Miftakhurozak.2018.Implementasi Metode Hypnoteaching Dalam Pembelajaran FAI.Ta'allum: Jurnal Pendidikan Islam., Vol. 6.

Mokhtar Masrurah,Et.al, Bahasa Indonesia untuk Perguruan Tinggi Makassar.La Macca Press. 2015.

Izzan, Ahmad. Metodologi Pembelajaran Bahasa Arab. Bandung: Humaniora. 2015

Izuddin Mustafa \& Hermawan Acep, Metodologi Penelitian Bahasa Arab. Bandung:Remaja Rosdakarya. 2018

Pilang, Abd. Rahman. Metodologi Penelitian. Makassar. Badan Penerbit UNM. 2013

Rosyid Zaiful Muh,Et.Al, Prestasi Belajar, Malang.Literasi Nusantara Abadi, 2019.

Rusdianto. Cepat dan Mudah Belajar Bahasa Arab. Yogyakarta. Laksana.2018

Saifuddin Mahmud, Strategi Belajar Mengajar, Banda Aceh, Syiah Kuala Press. 2017.

Syafril, Statistik Pendidikan, Jakarta:Prenamedia, 2019

Taufik Wildan, Metode Penelitian Bahasa Arab,.Bandung:Refika Aditama.2018

Ula Shoimatul.S, Revolusi Belajar, Yogyakarta:Ar-Ruzz Media.2013.

Widiasworo Erwin, Menyusun Penelitian Kuantitatif untuk skripsi dan tesis, Yogyakarta,Araska:2019.

Yudistira Yuan, Kekuatan Pikiran Alam Bawah Sadar,Jakarta:Gramedia,2019

Zulhannan. Teknik Pembelajaran Bahasa Arab Interaktif. Jakarta: Rajagrafindo Persada.2014

Zulifan, Muhammad. Bahasa Arab Untuk Semua. Jakarta: PT Gramedia Pustaka Utama.2018 